\title{
GC-MS ANALYSIS OF PHYTOCHEMICALS FROM THE EXTRACT OF Hibiscus sabdariffa GROWN IN NORTHERN NIGERIA
}

\author{
G.J. Okore $^{1 *}$, E. E. Oguzie ${ }^{1}$, C. E. Ogukwe ${ }^{1}$ and C. O. Akalezi ${ }^{1}$ \\ ${ }^{1}$ Department of Chemistry, AlvanIkoku Federal College of Education, Owerri, Imo State \\ *Corresponding author: gloryokore150@yahoo.com Phone number: +2348038970248 \\ Received 11 November 2020; accepted 16 March 2021, published online 10 April 2021
}

\begin{abstract}
Hibiscus sabdariffa, also known as Roselle belongs to Malvacae family. It is popularly known in Nigeria as Zobo. It has been used traditionally to cure certain ailments like cold, due to its rich pharmacological potential. Hence this study aimed at validating the pharmacological potential of Hibiscus sabdariffa by identification of the compounds present in its leaves using GC-MS technique. The extract was obtained by heating the leaves in ethanol under reflux. The ethanol extract was then subjected to GC-MS analysis. The constituents were identified by comparing their mass fragmentation (MS) pattern with those gathered in the library of NIST-MS and with those reported in literature. The graph obtained from the study revealed the presence of nine (9) organic compounds in Hibiscus sabdariffa leaf extract (HSLE) namely cyclohexane carboxylic acid ester, cyclopropane carboxylic acid methyl ester, hexanoic acid-4-octyl ester, hexadeca-2-11-dienoic acid, nhexadecanoic acid, oleic acid, octadecanoic acid, E-13-docosenoic acid and E-11-hexadecanal. Oleic acid has the highest peak value with the retention time of 20.711 which makes it the most abundant fraction and the active ingredient in the HSLE. The presence of some of these bioactive compounds has proved the scientific evidences for the antihypertensive and anti-inflammatory properties of the plant.
\end{abstract}

Key words: Phytochemical, GC-MS, Hibiscus sabdariffa, evaluation.

\section{Introduction}

Medicinal plants are the richest bio-resource of drugs of traditional systems of medicine, modern medicines, nutraceuticals, food supplements, folk medicines, pharmaceutical intermediates and chemical entities for synthetic drugs [1].

Oluwaseun and Abdurahman [2] identified a total of sixteen (16) compounds from the flower extract of Hibiscus sabdariffa using GC-MS analysis. Most of the compounds discovered were fatty acids and esters. Fatty acids are very useful in the pharmaceutical and food industries.Heshamet al. [3] identified fifteen (15) phytocompounds through the GC-MS analysis of methanol extract of the flower of Hibiscus sabdariffa. These compounds which have biological activities include ethanimidic acid, ethyl ester (31.43\%), propanal, 2,3-dihydroxy (12.58\%), 4H-Pyran-4-one, 2,3dihydro-3,5-dihydroxy-6-methyl (10.69\%), among others.

Compounds from plants continue to play a major role in primary health care as therapeutic remedies in many developing countries [4]. Plant-based natural constituents can be derived from any part of the plant like flowers, leaves, bark, roots, fruits, seeds [5]. Screening active compounds from plants has led to the invention of new medicinal drugs which have different protection and treatment roles against various diseases, including cancer [6] and
Alzheimer's disease [7] and also has a biological activity like antibacterial, antioxidants and antifungal.GC-MS is the best technique to identify the bioactive constituents of long chain hydrocarbons, alcohols, acids, esters, ethers etc.[8].Hibiscus flower was reported to contain fats, acids, flavonoids, carbohydrates, proteins and minerals [9]. Several studies describing the antihypertensive, hepatoprotective, anticancer, antidiabetic, cytotoxicity, antibacterial, antinociceptive, antiinflammatory and antioxidant activities of the flowers among others have been published [10].

Nandagopalanet al [1] investigated by GC-MS technique to determine the possible chemical components from the methanol extract of Hibiscus tiliaceuss, the result of which revealed the presence of $\mathrm{N}, \mathrm{N}-$ Dimethylglycine $(83.97 \%), 3,7,11,15$ Tetramethyl-2 hexadecen-1-ol (2.94\%) and $4 \mathrm{H}-$ Pyran-4-one, 2,3-dihydro-3,5 dihydroxy-6-methyl (2.69\%), thus providing scientific evidences for the antimicrobial, anticancer, antioxidant and antidiabetic properties of the plant.Layth [11] identified through GC-MS analysis of water extract from calyxes of the untreated karkade 4 bioactive constituents: 3,7,11,15-tetramethyl-2-hexadecen-1ol; 1,1-bicyclohexyl, 2-(2-methylpropyl)-trans; 3buten-2-one,4- (2-hydroxy-2,6,6trimethylcyclohexyl); and 1,2-benzenedicarboxylic 
acid, diisooctyl ester.Tuhami and Ibrahim [12] identified through GC-MS analysis 31 fatty acid ester derivatives from the essential oils obtained from seed of Hibiscus sabdariffa, the majority of which include: Hexadecanoic acid, methyl ester (16.94\%), 9,12- Octadecadienoic acid (Z,Z) -, methyl ester (21.93\%), 9, -Octadecadienoic acid

(Z), methyl ester (30.11\%), methyl stearate $(7.39 \%)$, Cyclopropaneoctanoic acid (3.17 $\%)$, Dotriacontane $(2.17 \%)$, two phenolic derivatives; 1,3-Benzodioxole,4methoxy-6-(2propenyl)- (0.01 \%) and Apiol (0.04 \%), two steroidal derivatives; 17 -Androstannone, 3-(3, 4dimethylphenyl) (1.81\%) and Stigmasta-4,7,22trien-3.beta.-ol $(0.41 \%)$ and three Pentacyclic triterpenes derivatives; Beta.-Amyrin (3.82\%) (3.17 \%), Alpha.-Amyrin (1.65\%) Urs-12-en-3-ol, acetate,(3.beta.) (1.17\%).

Shen et al [13] identified a total of 18 volatile constituents by GC-MS analysis of essential oil derived from the calyx of Hibiscus sabdariffa, the majority of which were fatty acids and ester compounds.Avalos-Martinez et al. [14] assessed the volatile compounds of Mexican hibiscus (Hibiscus sabdariffa L.) calyces and identified a

\section{GC-MS Analysis}

The analysis was carried out on a GC-MS spectrometer filled with an HP-5 MS (5\% phenylsiloxane) column at a temperature total of 104 volatile compounds, some of which include 2-Furfural, 5-methyl-2-furfural, hexanal, E-2-hexenal, (Z)-3-hexen-1-ol, 1-oten-3-one, 1octen-3-ol, 5-methyl-2 (3H)-furanone among others.

Considering the magnitude and potential of drug discovery from medicinal plants in health and economy, the present study aimed at validating the pharmacological potential of Hibiscus sabdariffa by identification of the compounds present in its leaves using GC-MS technique.

\section{Materials and Methods}

\section{Sample Collection and Extraction}

The dry leaves of Hibiscus sabdariffa were obtained from the local market. $10 \mathrm{~g}$ of the dry leaves were added to $400 \mathrm{ml}$ of ethanol contained in a $500 \mathrm{ml}$ round-bottomed flask and the resulting solution was heated under reflux for $3 \mathrm{hrs}$, allowed to cool at room temperature and then filtered. The ethanol content of the filtrate was evaporated using rotary evaporator and the obtained slurry was stored in air tight container and kept away from the sun for further experiment.

programme of $70^{\circ} \mathrm{C}$ (2 minutes) increase at $10^{\circ}$ $\mathrm{C} / \mathrm{min} 280^{\circ} \mathrm{C}$ and held for 7 minutes. The carrier gas was nitrogen and flow rate, $1.80 \mathrm{ml} / \mathrm{min}$. The GC-MS analysis was done on a Shimadzu GC-MS QP2010 at NARICT Zaria. 


\section{Results and Discussion}

The results of the GC-MS analysis are presented in figures and tables as follows:

Table 1: Chemical Composition of Hibiscus sabdariffaleaf extract (HSLE)

\begin{tabular}{|c|c|c|c|c|c|c|}
\hline Peak & NAME & $\begin{array}{l}\text { m. } \\
\text { formula }\end{array}$ & m. wt & $\begin{array}{l}\text { Retention } \\
\text { time }\end{array}$ & $\%$ oil & $\begin{array}{l}\text { Fragmentation } \\
\text { pattern }\end{array}$ \\
\hline 1 & $\begin{array}{l}\text { Cyclohexane } \\
\text { carboxylic } \\
\text { acid ethyl } \\
\text { ester }\end{array}$ & $\mathrm{C}_{9} \mathrm{H}_{16} \mathrm{O}_{2}$ & 156 & 6.740 & 2.64 & $\begin{array}{l}26(10) 27(30) 41(60) 55(199) \\
67(30) 83(30) 101(50) 112(5) \\
128(30) 141(10) 156(50)\end{array}$ \\
\hline 2 & $\begin{array}{l}\text { Cyclopropane } \\
\text { carboxylic } \\
\text { acid methyl } \\
\text { ester }\end{array}$ & $\mathrm{C}_{6} \mathrm{H}_{8} \mathrm{O}_{2}$ & 112 & 7.908 & 1.98 & $\begin{array}{l}33(5) 39(50) 53(100) 69(40) \\
81(100) 83(30) 101(50) 112(5) \\
128(30) 141(10) 156(50)\end{array}$ \\
\hline 3 & $\begin{array}{l}\text { Hexanoic } \\
\text { acid-4-octyl } \\
\text { ester }\end{array}$ & $\mathrm{C}_{14} \mathrm{H}_{28} \mathrm{O}_{2}$ & 228 & 12.972 & 0.33 & $\begin{array}{l}27(40) 41(70) 43(90) 57(40) \\
84(10) 99(100) 112(10) 129(5) \\
171(5) 171(5) 185(5)\end{array}$ \\
\hline 4 & $\begin{array}{l}\text { Hexadeca- } \\
2,11 \text {-dienoic } \\
\text { acid }\end{array}$ & $\mathrm{C}_{16} \mathrm{H}_{32} \mathrm{O}_{2}$ & 254 & 17.446 & 2.65 & $\begin{array}{l}41(80) 85(100) 69(60) 83(20) \\
97(40) 123(10) 138(10) \\
152(10) 192(5) 236(15)\end{array}$ \\
\hline 5 & $\begin{array}{l}\mathrm{n}- \\
\text { Hexadecanoic } \\
\text { acid }\end{array}$ & $\mathrm{C}_{16} \mathrm{H}_{34} \mathrm{O}_{2}$ & 256 & 17.794 & 16.13 & $\begin{array}{l}27(20) 41(180) 43(100) 60(85) \\
73(98) 83(20) 98(15) 115(15) \\
129(30) 157(10) 171(10) \\
185(10) 213(10) 256(30)\end{array}$ \\
\hline 6 & Oleic acid & $\mathrm{C}_{18} \mathrm{H}_{34} \mathrm{O}_{2}$ & 282 & 20.711 & 57.05 & $\begin{array}{l}27(30) 41(100) 55(90) 65(50) \\
83(40) 97(30) 264(15) 123(10) \\
137(10)\end{array}$ \\
\hline 7 & $\begin{array}{l}\text { Octadecanoic } \\
\text { acid }\end{array}$ & $\mathrm{C}_{18} \mathrm{H}_{36} \mathrm{O}_{2}$ & 284 & 20.938 & 11.49 & $\begin{array}{l}27(30) 41(100) 60(30) 73(80) \\
85(30) 98(20) 115(20) 129(40) \\
143(10) 171(10) 185(30) 199(10) \\
227(10) 241(20) 283(40)\end{array}$ \\
\hline 8 & $\begin{array}{l}\text { E-13 } \\
\text { Docosenoic } \\
\text { acid }\end{array}$ & $\mathrm{C}_{22} \mathrm{H}_{42} \mathrm{O}_{2}$ & 338 & 23.749 & 3.65 & $\begin{array}{l}27(40) 41(100) 55(98) 69(60) \\
81(50) 97(40) 98(70) 112(20) \\
137(15) 152(10)\end{array}$ \\
\hline 9 & $\begin{array}{l}\text { E-11- } \\
\text { Hexadecanal }\end{array}$ & $\mathrm{C}_{16} \mathrm{H}_{30} \mathrm{O}$ & 238 & 26.0212 .64 & 4.10 & $\begin{array}{l}41(80) 55(10069(60) 81(50) \\
95(45) 121(20) 135(15) 149(10) \\
220(20) 238(10)\end{array}$ \\
\hline
\end{tabular}


Table 2: Molecular structure of Hibiscus sabdariffaleaf extract (HSLE)

NAME MOLECULAR STRUCTURE

Cyclohexane carboxylic acid ethyl ester

Hexanoic acid-4-octyl ester

\section{Cyclopropane carboxylic acid methyl} ester<smiles>CCOC(=O)C1CCCCC1</smiles><smiles>CCCCC(CCC)OC(=O)CCCCCC1CC1C(=O)OC</smiles>

Hexadeca-2,11-dienoic acid n-Hexadecanoic acid

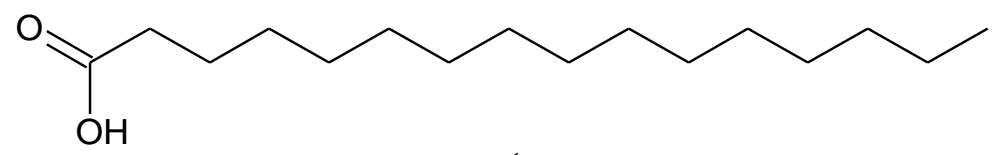

\section{Oleic acid}

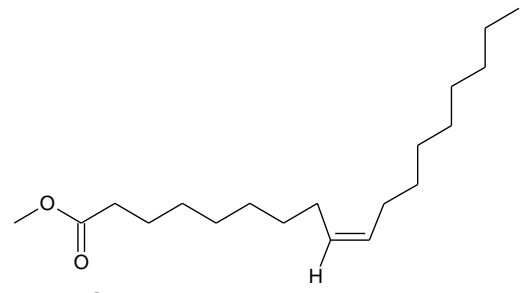

\section{Octadecanoic acid}

\section{E-13 Docosenoic acid}

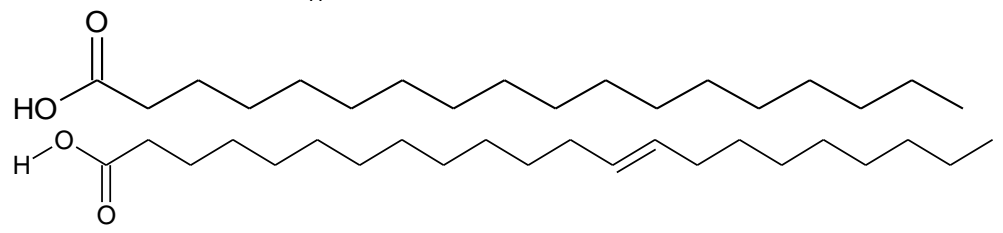

E-11-Hexadecanal

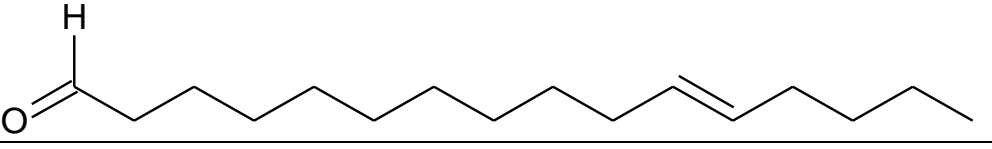

The result of the GC-MS of the HSLE showed nine (9) peaks indicating that nine compounds were identified. Compound 1 is Cyclohexane carboxylic acid ethyl ester with molecular formula $\mathrm{C}_{9} \mathrm{H}_{16} \mathrm{O}_{2}$ and percentage composition of $2.64 \%$. Compound 2 is Cyclopropane carboxylic acid methyl ester with molecular formula $\mathrm{C}_{6} \mathrm{H}_{8} \mathrm{O}_{2}$ and Compound 5 is n-Hexadecanoic acid with molecular formula $\mathrm{C}_{16} \mathrm{H}_{34} \mathrm{O}_{2}$ and percentage composition of $16.13 \%$. Compound 6 is oleic acid with molecular formula $\mathrm{C}_{18} \mathrm{H}_{34} \mathrm{O}_{2}$ and percentage percentage composition of $1.98 \%$. Compound 3 is Hexanoic acid-4-octyl ester with molecular formula $\mathrm{C}_{14} \mathrm{H}_{28} \mathrm{O}_{2}$ and percentage composition of $0.33 \%$. Compound 4 is Hexadeca-2,11-dienoic acid with molecular formula $\mathrm{C}_{16} \mathrm{H}_{32} \mathrm{O}_{2}$ and percentage composition of $2.65 \%$.

composition of $57.05 \%$. Compound 7 is Octadecanoic acid with molecular formula $\mathrm{C}_{18} \mathrm{H}_{36} \mathrm{O}_{2}$ and percentage composition of $11.49 \%$. Compound 8 is E-13 Docosenoic acid with 
molecular formula $\mathrm{C}_{22} \mathrm{H}_{42} \mathrm{O}_{2}$ and percentage composition of $3.65 \%$. Compound 9 is E-11Hexadecanal with molecular formula $\mathrm{C}_{16} \mathrm{H}_{30}$ Oand percentage composition of $4.10 \%$. Oleic acid has the highest peak value with retention time of 20.711 which makes it the most abundant fraction and the active ingredient in the HSLE.

The result of the GC-MS analysis of Hibiscus tiliaceuss extract by [1] revealed the presence of N,N-Dimethylglycine $\quad(83.97 \%), \quad 3,7,11,15$ Tetramethyl-2-hexadecen-1-ol (2.94\%) and provides scientific evidence for the antimicrobial, anticancer and antidiabetic properties of the plant.Layth [11] identified some bioactive constituents: 3,7,11,15-tetramethyl-2-hexadecen-1ol, diisooctyl ester, benzene dicarboxylic acid from the GC-MS analysis of the calyxes of Karkade (Hibiscus sabdariffa).Tuhami and Ibrahim [12] identified 31 fatty acid ester derivatives from seed of Hibiscus sabdariffa through GC-MS, majority of which include Hexadecanoic acid, methyl ester (16.94\%), 9,12-octadecadienoic acid (Z), methyl ester $(30.11 \%)$ among others.Shen et al. [13] identified a total of 18 volatile constituents by GCMS analysis of essential oil derived from the calyx of Hibiscus sabdariffa, majority of which were fatty acids and ester compounds.GC-MS analysis carried out by [2] on Hibiscus sabdariffa (HS) flower oil reveals the presence of fatty acids, thiol, sesquiterpenes, acyclicditerpene alcohol and phenolic monoterpenoids as the main chemical components of the HS flower oil. Among the fatty acids are 4-methoxy-2-thiophene carboxylic acid, cyclopentane carboxylic acid, n-hexadecanoic acid, 9,12-octadecadienoic acid (Z,Z)-, oleic acid, dodecanoic acid, 4-pentenoic acid ethyl aster, 9octadecenoic acid (Z)- and n-nonanoic acid.GCMS analysis of [3] revealed the presence of fifteen neurogenesis, prevent neuroinflammation and apoptosis, promote brain development, ameliorate cognitive functions etc. [22]. Oleic acid may also be responsible for the hypotensive (or blood pressure reducing) effects of olive oil [23]. Anaet al. [24] in their book titled "Biochemistry and health benefits of fatty acids reviews plant-based fatty acids as well as their methods of production, applications in the industry, and benefits in treatments of cardiovascular and cerebral diseases, besides being a source of food. The fatty acids obtained from vegetable matrices have been acting as alternatives to the use of lipids of animal origin, compounds among which are propanamide, Nethyl, ethylenediamine, ethoxy-, hexadecanoic acid, methyl ester, butanedial among others. These results are in agreement with the present study.

The present study revealed Hibiscus sabdariffaleaf as a potential source of fatty acids. Fatty acids are divided into four categories namely saturated, mionounsaturated, polyunsaturated and trans fats [15]. Essential fatty acids have important cellular functions and have been suspected to have antiinflammatory properties and they should form a necessary part of human diet since the body cannot produce these molecules on its own [15]. Cyclohexane carboxylic acid ethyl ester has been reported as a flavouring agent used in foods including condiments and seasonings [16]. Cyclopropane carboxylic acid methyl ester is primarily used as an intermediate in the manufacture of pharmaceutical and agrochemical products. Getliket al.[17] has identified methyl cyclopropane carboxylate as a reagent for the synthesis of $\mathrm{N}^{1}$-thiazole and $\mathrm{N}$-pyrazole based inhibitors of MAP kinase $\mathrm{p} 38 \alpha$. The compound nhexadecanoic acid is used as anti-inflammatory compound. The work of [18] validates the rigorous use of oils rich in n-hexadecanoic acid for the treatment of rheumatic symptoms in the traditional medical system of India. Oleic acid $(57.05 \%)$ obtained from the present study is a well-known monounsaturated fatty acid. Oleic acid is used as an excipient in pharmaceuticals and as an emulsifying or solubilizing agent in aerosol product[19]. It may hinder the progression of adrenoleukodystrophy, a fatal disease that affects the brain and adrenal glands [20,21]. Fatty acids boost synaptogenesis and

due to their limitation in relation to the increase in demand and so plants have been investigated in order to act as sources of fatty acids and assist in the supply of such demands and vegetable oils represent not only an economical alternative but also a beneficial source of human health [24].

\section{Conclusions}

The present study identified nine different compounds from the ethanol extract of Hibiscus sabdariffa leaf. It has been shown, in comparison with similar work and from literature, that the identified compounds and their derivatives have 
very rich pharmacological potentials. Hence it is recommended that further work could be done on the identified compounds and their derivatives which could be put to more usefulness pharmacologically and industrially as well.

\section{References}

1. V. Nandagopalan, M. Johnson and A. Doss (2015). GC-MS analysis of bioactive components of the methanol extract of Hibiscus lilaceus 1, Asian Journal of Plant Science and Research 5 (3): 6-10

2. R.A. Oluwaseun and H.A. Nour (2019). GCMS and FTIR analyses of oils from Hibiscus sabdariffa, Stigma maydis and Chromolaena odorata, Chemical data collections,20htttps://doi.org/10.1016/j.cdc.201 9.

3. H.A.R. Hesham, H.A. Nour and M.Y. Rosli (2017). GC-MS analysis of bioactive constituent of Hibiscus flower, Australian Journal of Basic and Applied Sciences, 11 (3): 91-97

4. V. Bobbarala, P.V. Bramhachari, J. Ravichand, Y.H.K. Reddy, D. Kotresha and K.V. Chaitanya (2011). Evaluation of hydroxyl radical scavenging activity and HPTLC fingerprint profiling of Aegle marmelois (L.) Correa extracts, J.Pharm Rs., 4 (1): 252-255.

5. D.M. Gordon (2001). Geographical structure and host specificity in bacteria and the implications for tracing the source of coliform contamination, Microbiology, 147: 1079-1085.

6. K. Sheeja and G. Kuttan (2007). Activation of cytotoxic $T$. lymphocyte responses and attenuation of tumor growth in vivo by Andrographis paniculate extract and andrographilide, Immunopharmacol Immunotoxicol., 29: 81-93.

7. P.K. Mukherjee, V. Kumar and P.J Houghton (2007). Screening of Indian medicinal plants for acetylcholinesterase inhibitory activity: Phytother Res., 21: 1142-1145

8. A. Muthulakshmi, R. J. Margaret and V.R. Mohan (2012). GC-MS analysis of bioactive components of Feroniaelephantum Correa (Rutaceae), App. Pharmac. Sci., 2: 69-74

9. N.S. Mahadevan and P. Kamboj (2009). Hibiscus sabdariffa Linn: An overview, Natural Product Radiance, 8 (1): 77-83.

10. L.H. Kristen, P.B. Kellie, Z. Svetlana, P.D. Michael and J.R.C.N. Stewart (2014).
Antimicrobial activity of Hibiscus sabdariffa aqueous extracts against Escherichia coli 0157:H7 and staphylococcus aureus in a microbiological medium and milk of various fat concentrations, Journal of Food Protection, 77 (2): 262-268

11. S. Layth (2017). Influence of multiwalled carbon nanotubes and biostimulators on growth and content of bioactive constituents of Karkade (Hibiscus sabdariffa), Journal of Botany, 1-11.

12. H. Tuhami and A. Ibrahim (2020). Phytochemical analysis, antibacterial and antioxidant activities of essential oil from Hibiscus sabdariffa seeds (Sudan Karkadi), Progress in chemical and biochemical research, 3, 194-201.

13. C. Shen, T. Zhang, W. Zhang and J. Jiang (2016). Anti-inflammatory activities of essential oil isolated from the calyx of Hibiscus sabdariffa, Food and Function 7 (10), 4451-4459

14. E. Avalos-Martinez, J. A. Pino, S. SayagoAverdi, O. Sosa-Moguel and L. Ceuvas-Glory (2019). Assesment of volatile compounds and sensory characteristics of Mexican Hibiscus (Hibiscus sabdariffa 1.) calyces hot beverages, Journal of Food Science and Technology, 56, 360-366.

15. W. Brett (2009). Dietary fatty acids, AM Fam Physician 80 (4): 345 -350.

16. S. Kim, J. Chen, T. Cheng, A. Gindulate, J. He, S. He, Q. Li, B.A. Shoemaker, P.A. Thiessen, B.Yu, L. Zaslavsky, J. Zhang and E.E. Bolton (2019). Pubchem update: Improved access to chemical data, Nucleic acid research, 47.

17. M. Getlik, C. Grutter, J.R. Simard, H.D. Nguyen, A. Robubi, B. Aust, W.A. Van Otterlo and D. Raud (2011). Structure based design, synthesis and biological evaluation of $\mathrm{N}$-pyrazole, $\mathrm{N}^{1}$-thiazole urea inhibitors of MAP Kinase p38 $\alpha, 48:$ 1-15.

18. A. Vasudevan, V. Dileep, M. Pradeep and K. Ponnuraj (2012). Anti-inflammatory property of N-Hexadecanoic acid: structural evidence and kinetic assessment, Chemical Biology and Drug Design 80 (30): 434-9.

19. N.H. Choulis (2011). A worldwide yearly survey of new data in adverse drug reactions, Side Effect of Drugs Annual, 33, 2-1103. 
20. W.B. Rizzo, P.A. Watkins, M.W. Phillips, D. Cramin, and B. Avigan (1986). "Adrenoleukodystrophy: Oleic acid lowers fibroblast saturated C 22-26 fatty acids", Neurology 36 (3): 357-361.

21. R.I. Uchegbu, LC. Ngozi-Olehi and R.U. Ogbuneke (2018). Phytochemical evaluation by GC-MS analysis of Zingiber officinale (Ginger) rhizome grown in eastern Nigeria, Alvana Journal of Science, 10, 128-131.

22. G. Hussain, F. Schmitt, J. Loeffer and G. JoseLuis (2013). Fatting the brain: a brief of recent research, Front Cell Neurosci. 7: 144.

23. S. Teres, G. Barcelo-Coblin, M. Benet, R. Alvorez, R. Bressani, J.E. Halver and P.V. Escriba (2008). Oleic acid content is responsible for the reduction in blood pressure induced by olive oil, Proc. Natl. Acad. Sci. 105, (3).

24. P. Ana, A. Wanessa, M. Rodriguez, P. Bezerra, C Flavia, C. Maria, G. Eduardo, R. Glides, R. Jhonias and R. de Carvalho (2018). Commercial and Therapeutic Potentials of Plant-Based

FattyAcid,https://www.intechopen.com/books/ biochemistry-and-health-benefits-of-fattyacids/commercial-and-therapeutic-potential-ofplant-based-fatty-acids. 